\title{
Phytic acid affects lipid metabolism in the rat
}

\author{
T. Szkudelski \\ Department of Animal Physiology and Biochemistry, \\ Poznań Agriculture University \\ Wotyńska 35, 60-637 Poznań, Poland
}

(Received 1 April 1998; accepted 22 September 1998)

\begin{abstract}
The effects of feeding rats a diet containing $0.2 \%$ added phytic acid for $5,10,15$ and 20 days (groups II, III, IV and V, respectively) on lipid metabolism were studied. The animals in group I (controls) were fed Murigran, a complete feed (from Motycz) without added phytic acid. It was found that phytic acid lowered free fatty acid levels in the blood. Their average concentration was $0.745 \pm 0.05 \mathrm{mmol} / \mathrm{L}$ in group I, $0.625 \pm 0.05$ in group II, $0.677 \pm 0.04$ in group JIJ, $0.590 \pm 0.04$ in group IV and $0.599 \pm 0.02 \mathrm{mmol} / \mathrm{L}$ in group $\mathrm{V}$. A significant decline in the triglyceride content in the liver also occurred under the influence of phytic acid: in group I $27.821 \pm 1.73 \mathrm{mmol} / \mathrm{kg}$, in group II $22.012 \pm 2.05$, in group III $24.420 \pm 1.48$, in group IV $20.206 \pm 0.75$ and in group V $22.101 \pm 1.40 \mathrm{mmol} /$ $\mathrm{kg}$. Phytic acid also increased the cholesterol content in whole blood serum (in group I $1.758 \pm 0.09$ $\mathrm{mmol} / \mathrm{L}$, in group II $1.997 \pm 0.06$, in group III $1.903 \pm 0.08$, in group IV $2.025 \pm 0.05$ and in group V $2.001 \pm 0.05 \mathrm{mmol} / \mathrm{L}$ ) as well as in the HDL fraction (in group I $0.514 \pm 0.03 \mathrm{mmol} / \mathrm{L}$, in group II $0.652 \pm 0.03$, in group III $0.639 \pm 0.05$, in group IV $0.672 \pm 0.02$ and in group V $0.636 \pm 0.03 \mathrm{mmol} / \mathrm{L}$ ). These changes may be a consequence of the inhibitory effect of phytic acid on the absorption of elements from the digestive tract or they may result from the action of the inositol that is formed as the result of dephosphorylation of phytic acid.
\end{abstract}

KEY WORDS: phytic acid, metabolism, lipids, rat

\section{INTRODUCTION}

Phytic acid (inositol hexaphosphate) is found in considerable amounts in the sceds of various species of plants commonly used in animal nutrition. It can even amount to about $2 \%$ of the dry matter of seeds (Reddy et al., 1982). It has repeatedly been found that changes in the supply of phytic acid in the diet have a notable 
effect on many metabolic processes. The most frequently observed is a decrease in the absorption of many trace and macroelements from the digestive tract that, under certain conditions, can lead to symptoms of deficiency (Davies and Nightingale, 1975; Tao et al., 1986; Couzy et al., 1993; Adeola et al., 1995). Moreover, phytic acid interferes in digestive processes, reducing protein (Kriuckles et al., 1985) and starch (Deshpande and Cheryan, 1984) degradation. A consequence of these effects can be a decline in nitrogen retention and a wcaker glycemic response in the absorptive phase (Yoon et al., 1983). The anti-neoplastic effects of phytic acid arc also known (Vucenik et al., 1993; Shamsuddin et al., 1997). On the basis of the studies of Szwergold et al. (1987) it is known that phytic acid also is found in mammalian cells, albcit in amounts much smaller than in plants. Its metabolic role is, however, still very little known. There is also a lack of information on the effect of dietary phytic acid on metabolism. Taking into account the ubiquity of this compound in plant feeds used in animal nutrition, elucidating its role seems to be justified.

The objective of this study was to ascertain the effect of feeding rats rations containing $0.2 \%$ added phytic acid for $5,10,15$ and 20 days on certain lipid metabolism parameters.

\section{MATERIAL AND METHODS}

\section{Animals and diets}

The experiment was conducted on 40 male Wistar rats with an initial body weight of $140 \pm 5 \mathrm{~g}$. The animals were divided into 5 groups $(\mathrm{n}=8)$ and were maintained under standard conditions. During the entire experiment the rats were fed ad libitum with a complete feed "Murigran" (made in Motycz, Poland). The feed composition (in \%) was: wheat bran, 10; maize meal, 17.5; oat meal, 20; fish meal, 8; skimmilk, 12; casein, 5.5; yeast, 5; grass meal, 5; vitamins and minerals, 2 . The $\mathrm{Zn}$ content was $56 \mathrm{mg} / \mathrm{kg}$ feed. The energy value of the feed was $12.8 \mathrm{MJ}$ metabolizable energy $/ \mathrm{kg}$; crude protein, $24 \%$; crude fibre, $3 \%$; and crude fat, $3.7 \%$. The rats in group I served as the controls, and were given the feed in which the natural phytic acid content was $0.47 \%$.

The animals in the remaining groups received the same feed with a $0.2 \%$ addition of phytic acid for 5 (group II), 10 (group III), 15 (group IV) or 20 days (group V). Phytic acid was added to crushed feed after being dissolved in water $(550 \mathrm{ml}$ solution $/ \mathrm{kg}$ feed) and then the feed was granulated and dried in a draft at $30^{\circ} \mathrm{C}$. The feed for the control animals was prepared in the same way, using water without phytic acid. Feeding the animals with the phytic acid-containing feeds was begun in five-day intervals between successive groups. After 20 days of the experi- 
ment, all of the animals were decapitated and their blood, liver and thigh muscles were sampled.

Triglycerides and total cholesterol were determined in the liver, and total cholesterol in muscles. Feed intake, body weight gain and liver mass gain were also determined.

\section{Chemical analysis}

The serum triglycerides level was determined using the method of Foster and Dunn (1973), free fatty acids were assayed by the method of Duncombe (1964). In addition, whole blood serum and the HDL fraction were used to determine total cholesterol. Cholesterol was determined by the enzymatic method of Richmond (1973). The amount of triglycerides in the liver was determined similarly as in serum after extraction of lipids using the method of Folch et al. (1975). The liver and muscle cholesterol extracted in this way was assayed using a diagnostic kit (POCh Gliwice, Poland).

Phytic acid (disodium salt) and the remaining analytical reagents were obtained from Sigma.

\section{Statistical analysis}

The results were subjected to statistical analysis by one factor analysis of variance and Duncan the multiple range test. The correlation coefficient (r) between the determined parameters and the duration of feeding the rats diet containing phytic acid were calculated at a level of significance of $\mathrm{P} \leq 0.05$.

\section{RESULTS}

The results of the experiment are presented in Tables 1 and 2. No effect of increased dietary phytic acid content was found on feed intake, body weight gain or liver weight.

All of the rats fed phytic acid demonstrated significant decreases in liver triglycerides (20.9\% in group II, $12.2 \%$ in group III, $27.4 \%$ in group IV and $20.6 \%$ in group $\mathrm{V}$ ) in comparison with the control group. These changes were significantly corrclated with the duration of feeding phytic acid diets $(\mathrm{r}=-0.38)$. The decline in serum free fatty acid levels was also significant: $16.1 \%$ in group II, $9.1 \%$ in group III, $20.8 \%$ in group IV and $19.6 \%$ in group V $(r=-0.34)$. Total serum cholesterol levels rose by $13.6,8.2,15.2$ and $13.8 \%$ in groups II, III, IV and V, respectively, as a result of feeding a phytic-acid supplemented diet $(r=0.31)$. A rising tendency was also observed in the amount of total cholesterol in high density lipoproteins in 
TABLE I

Effect of phytic acid supplemented diet on diet intake, body weight gain and liver weight

\begin{tabular}{lccccc}
\hline & \multicolumn{5}{c}{ Group } \\
\cline { 2 - 6 } & I-0 days* & II-5 days* & III-10 days* & IV-15 days* & V-20 days* \\
\hline Diet intake, g/day & $12.19 \pm 1.61$ & $12.39 \pm 1.54$ & $11.99 \pm 10.40$ & $12.01 \pm 2.34$ & $11.59 \pm 2.32$ \\
Body weight gain,g/day & & & & & \\
$\quad 5$ days & $6.11 \pm 0.99$ & $5.36 \pm 0.89$ & & & \\
10 days & $5.87 \pm 0.68$ & & $5.98 \pm 0.68$ & & \\
15 days & $5.81 \pm 0.84$ & & & $5.31 \pm 0.55$ & \\
20 days & $4.88 \pm 0.91$ & & & & $4.87 \pm 0.49$ \\
Liver weight g/100 g BW & $3.15 \pm 0.05$ & $3.17 \pm 0.06$ & $3.02 \pm 0.06$ & $3.20 \pm 0.05$ & $3.23 \pm 0.08$ \\
\hline
\end{tabular}

values are means + SEM for eight animals

* - lime of feeding with $0.2 \%$ phytic acid addition

rats. This rise equaled $26.8 \%$ in group II, $24.3 \%$ in group III, $30.7 \%$ in group IV and $23.7 \%$ in group $\mathrm{V}(\mathrm{r}=0.32)$. The ratio of HDL cholesterol to total serum cholesterol also increased by $11.6 \%$ in group II, $14.5 \%$ in group III, $14.2 \%$ in group IV and $12.1 \%$ in group $\mathrm{V}(\mathrm{r}=0.26)$. The cholesterol content in the liver of animals fed the diets with added phytic acid declined slightly. This change was significant only in group $\mathrm{V}$ (a $7.0 \%$ decline) in comparison with the control group and was significantly correlated with the duration of fecding the phytic-acid supplemented feed $(r=-0.36)$. The cholesterol content of muscles did not change significantly.

\section{DISCUSSION}

This experiment has shown that when phytic acid is supplied to rats at a rate of $0.2 \%$ of the ration, it is a material factor interfering in lipid metabolism. This is shown, among others, by the changes in the free fatty acid and cholesterol levels in the blood serum and liver of animals as early as after only 5 days of feeding them a diet containing $0.2 \%$ of this compound.

Phytic acid consumed in food may affect metabolism in various ways. Sakamoto et al. (1993) found that a certain amount of this compound undergoes dephosphorylation in the digestive tract, and that the products of dephosphorylation, mainly myo-inositol, are absorbed into the blood and reach many internal organs and tissues. Phytic acid may therefore exert its effects through the inositol that is formed from it. It seems very likely that lowering the liver triglyceride level in rats fed phytic acid-containing feed is caused by inositol. This supposition is corroborated by the results of another study in which rats were given drinking water containing inositol or phytic acid. Both of these compounds equally distinctly lowered the liver triglyceride reserves in these animals (Szkudelski et al., 1997). Earlicr, An- 


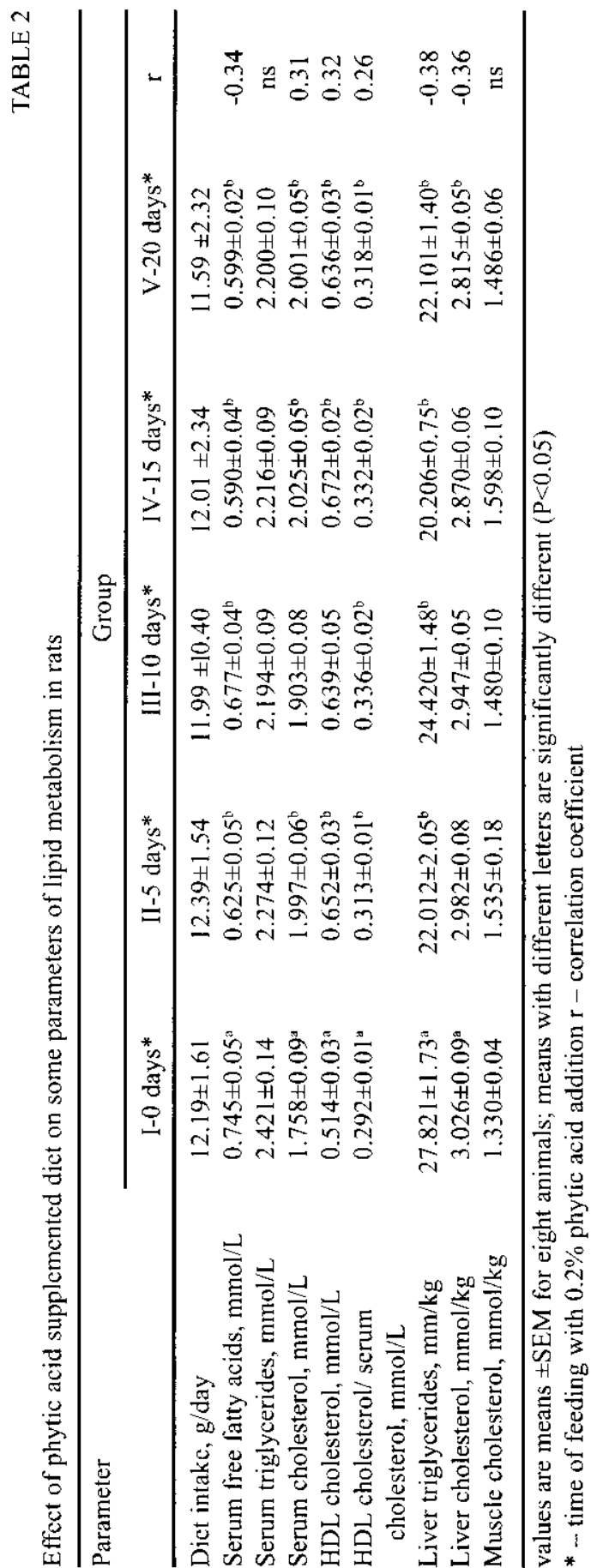


dersen and Holub (1980) used myo-inositol as an additive to feeds for rats and also found a rapid decline in triglycerides myo-inositol in the liver. By acting through inositol, phytic acid is therefore an important dietary factor limiting the accumulation of triglycerides in the liver.

These changes are observed after only five days of feeding rats feeds with added phytic acid and may increase slightly with time.

The lowered serum free fatty acid concentration may be caused by inhibition of lipolysis, increased utilization of these acids as sources of energy, or intensified reesterification in the liver. The latter seems little probable, since a rise in triglycerides in the liver and serum was not observed. Inhibition of lipolysis may be a consequence of hypotyreosis found in rats as an effect of phytic acid in another study (Chichłowska et al., 1994). Despite significant changes in adipose tissue metabolism, the serum triglycerides level may remain unchanged (Murase and Uchimura, 1980).

Animals fed diets with elevated phytic acid contents were also found to have higher cholesterol levels in whole serum and in the HDL fraction. It is believed that a higher cholesterol level in this fraction is favourable and is an important factor in preventing coronary heart disease (Miller and Miller, 1975) and atherosclerosis (Patsch et al., 1978). This is related to the fact that high density lipoproteins transport cholesterol from peripheral tissues to the liver, helping in this way to eliminate it (Mahley, 1981). A rise in HDL cholesterol is positively correlated with lipoprotein lipase activity (Taskipen and Kuusi, 1987) and may be a consequence of lowered liver lipase activity (Kuusi et al., 1979). Normal cholesterol metabolism is dependent on the supply of certain elements in the diet. This pertains to zinc in particular. Phytic acid is a compound that inhibits the absorption of this element from the digestive tract. (Couzy et al., 1993; Adcola et al., 1995). In the case of a zinc deficit, the whole cholesterol level and HDL cholesterol levels rise (Lei, 1983). This is a very similar pattern to the changes we found in this experiment. One of the reasons for this condition is the prolonged half-life of plasma cholesterol in the HDL fraction (Lei i Lin, 1981) that is a conscquence of limited take up of cholesterol by the liver from this fraction (Lei, 1983).

In the present studies, the liver cholesterol content fell, which may be a consequence of the take up of this lipid by the liver. Changes in the cholesterol content in rats receiving feeds with added phytic acid may therefore result from the inhibitory effect of this compound on the absorption of zinc and/or from changes in the activity of the mentioned enzymes that take part in cholesterol metabolism. Worth noting is that phytic acid supplied in the diet may cause distinct changes in cholesterol metabolism as early as in five days. It does, however, take longer for the changes to become apparent in the liver.

The results of this experiment show that the addition of $0.2 \%$ phytic acid to the diet of rats is a significant factor altering lipid metabolism. The metabolic changes 
may occur after only a short period of feeding rats a diet with this additive. In the present experiment, these changes were distinctly visible after only 5 days and only slightly intensified over the next 15 .

\section{REFERENCES}

Adeola O., Lawrence B.V., Sutton A.L., Cline T.R., 1995. Phytase-induced changes in mineral utilisation in zinc-supplemented diets for pigs. J. Anim. Sci. 73, 3384-3391

Andersen D.B., Holub B.J., 1980. Mio-inositol-responsive liver lipid accumulation in the rat. J. Nutr. $110,488-495$

Chichłowska J., Szkudelski T., Kliber A., 1994. Is phytic acid responsible for changes in thyroid hormones and insulin levels? Proceedings of the IV International Conference Euro Food Tox, Olsztyn (Poland), 2, 351-354

Couzy F., Kastenmayer P., Mansourian R., Guinchard S., Munoz-Box R., Dirren H., 1993. Zinc absorption in healthy elderly humans and the effect of diet. Amer. J. Clin. Nutr. 58, 690-694

Davies N.T., Nightingale R., 1975. The effects of phytate on intestinal absorption and secretion of zinc, and whole-body retention of $\mathrm{Zn}$. copper, iron and manganese in rats. Brit. J. Nutr. 34, 243-258

Deshpande S.S., Cheryan M., 1984. Effect of phytic acid. divalent cations, and their interactions on $\alpha$-alnylase activity. J. Food Sci. 49, 515-520

Duncombe D., 1964. The colorimetric micro-determination of nonesteryfied fatty acids in plasma. Clin. Chim. Acta 9,122-125

Folch J., Lees M., Sloane G.S.H., 1975. A simple method of the isolation and purification of total lipids from animal tissues. J. Biol. Chem. 226, 497-509

Foster L.B., Dunn R.T., 1973. Stable reagents for determination of serum triglycerides by a colorimetric Hatzsch condensation method. Clin. Chem. 19, 338-340

Knuckles B.E., Kuzmicky D.D., Betschart A.A., 1985. Effect of phytate and partially hydrolysed phytate on in vitro protein digestibility. J. Food. Sci. 50, 1080-1082

Kuusi T., Kinnunen P.K.J., Nikkila E.A., 1979. Hepatic endothelial lipase antiserum influences rat plasma low and high density lipoproteins in vivo. FEBS Lett. 104, 384-388

Lei K.Y., 1983. Alterations in plasma lipid, lipoprotein and apolipoprotein concentrations in copperdeficient rats. J. Nutr. 113,2178-2183

Lei K.Y., Lin I.M., 1981. Kinetics of high density lipoprotein cholesterol in copper-deficient rats. Nutr. Rep. Int. 24, 1179-1186

Mahley R.W., 1981. Cellular and molecular biology of lipoprotein metabolism in atherosclerosis. J. Amer. Diabetes Assoc. 30, 60-65

Miller G.J., Miller N.E., 1975. Plasma high-density lipoprotein concentration and development of ischaemic heart disease. Lancet 1,16-19

Murase T., Uchimura H., 1980. A selective decline of postheparin plasma hepatic triglyceride lipase in hypothyroid rats. Metabolism 29, 797-801

Patsh J.R., Gotto A.M., Olivecrona T., Eisemberg S., 1978. Formation of high density lipoprotein,like particles and lipolysis of very low density lipoproteins in vitro. Proc. Natl. Acad. Sci. USA $75,4519-4523$

Reddy N.R., Sathe S.K., Salunkhe D.K., 1982. Phytates in legumes and cercals. Adv. Food Res. $28,1-92$ 
Richmond W., 1973. Preparation and properties of a cholesterol oxidase from Nocardia sp. and its application to the enzymatic assay of total cholesterol in serum. Clin. Chem. 19, 1350-1356

Sakamoto K., Vucenik I., Shamsuddin A.M., 1993 [ $\left.{ }^{3} \mathrm{H}\right]$ Phytic acid (inositol hexaphosphate) is absorbed and distributed to various tissues in rats. J. Nutr. 123, 713-720

Shamsuddin A.M., Vucenik I., Cole K.E., 1997. IP6: a novel anti-cancer agent. Life Sci. 61, 43-354

Szkudelski T., Chichłowska J., Kliber A., 1997. Effect of inositol and phytic acid on triglycerides content in rat tissues (in Polish). Proceedings of XXXIII Congress of Polish Biochemical Society, Katowice (Poland), p. 175

Szwergold B.S., Graham R.A., Brown T.R., 1987. Observation of inositol pentakis- and hexakisphosphates in mammalian tissues by ${ }^{3}$ P NMR. Biochim. Biophys. Res. Commun. 149, 874-881

Tao S.H., Fox M.R.S., Phillippy B.Q., Fry B.E. Jr., Johnson M.L., Johnston M.R., 1986. Effect of inositol phosphates on mineral utilisation. Fed. Proc., Fed. Amer. Soc. Exp. Biol. 45, 819-827

Taskinen M.R., Kuusi T., 1987. Enzymes involved in triglyceride hydrolysis. Bailliers Clin. Endocrinol. Metab. 1, 639-666

Vucenik I., Sakamoto K., Bansal M., Shamsuddin A.M., 1993. Inhibition of rat mammary carcinogenesis by inositol hexaphosphate (phytic acid). A pilot study. Cancer Lett. 75, 95-102

Yoor J.H., Thompson L.U., Jenkins D.J.A., 1983. The effect of phytic acid on in vitro rate of starch digestibility and blood glucose response. Amer. J. Clin. Nutr. 38, 835-842

\section{STRESZCZENIE}

\section{Wpływ kwasu fitynowego na przemianę thuszczową u szczura}

Określono wpływ żywienia szczurów przez 5, 10, 15 i 20 dni (odpowiednio grupa II, III, IV i V) paszą z $0,2 \%$ dodatkiem kwasu fitynowego na przemianę tłuszczową. Zwierzęta z grupy I (kontrolnej) otrzymywały pasze, pełnoporcjową mieszankę Murigran (Gospodarstwo Rybackie w Motyczu), bez dodatku tego związku. Stwierdzono, że kwas fitynowy powoduje obniżenie zawartości wolnych kwasów thuszczowych we krwi. Średnie ich stężenie wynosiło $0,745 \pm 0,05 \mathrm{mmol} / \mathrm{L}$ w grupie I, $0,625 \pm 0,05 \mathrm{w}$ grupie II, $0,677 \pm 0,04 \mathrm{w}$ grupie, III $0,590 \pm 0,04 \mathrm{w}$ grupie IV i $0,599 \pm 0,02$ $\mathrm{mmol} / \mathrm{L}$ w grupie V. Pod wpływem kwasu fitynowego wystapiło także istotne obniżenie zawartości triglicerydów w wątrobie: w grupie I $27,821 \pm 1,73 \mathrm{mmol} / \mathrm{kg}$, w grupie II $22,012 \pm 2,05$, w grupie III $24,420 \pm 1,48$, w grupie IV $20,206 \pm 0,75$, grupie V 22,101 $\pm 1,40 \mathrm{mmol} / \mathrm{kg}$. Kwas fitynowy spowodował również wzrost ilości cholesterolu w całej surowicy krwi (w grupie I, 1,758 $\pm 0,09 \mathrm{mmol} / \mathrm{L} \mathrm{w}$ grupie II $1,997 \pm 0,06$, w grupie III $1,903 \pm 0,08$, w grupie IV $2,025 \pm 0,05$ i w grupie V $2,001 \pm 0,05$ $\mathrm{mmol} / \mathrm{L}$ ) oraz we frakcji HDL (w grupie I $0,514 \pm 0,03 \mathrm{mmol} / \mathrm{L}$, w grupie $1 \mathrm{l} 0,652 \pm 0,03$, w grupie III $0,639 \pm 0,05$, w grupie IV $0,672 \pm 0,02 \mathrm{i}$ w grupie V $0,636 \pm 0,03 \mathrm{mmol} / \mathrm{L}$ ). Obserwowane zmiany mogą być następstwem hamującego wpływu kwasu fitynowego na absorpcję pierwiastków z przewodu pokarmowego oraz mogą być następstwem $\mathrm{z}$ działania inozytolu powstającego $\mathrm{w}$ wyniku jego defosforylacji. 